\title{
Connectivity between Pedestrian Ways and Bus Rapid Transit Shelter in Banyumanik and Pedurungan, Semarang
}

\author{
Diah Intan Kusumo Dewi ${ }^{1, \text { a) }}$ and Anita Ratnasari Rakhmatulloh ${ }^{1, \text { b) }}$ \\ ${ }^{1}$ Department of Regional and Urban Planning, Faculty of Engineering, Diponegoro University \\ a) Corresponding author: diah.intan@pwk.undip.ac.id \\ b) anita.ratnasari.r@pwk.undip.ac.id
}

\begin{abstract}
The high rate of human movement drives the need for human circulation pathways and adequate transportation systems. To solve this problem, the Semarang City government has actually built transportation facilities in the form of BRT (Bus Rapid Transit) along with pedestrian ways. However, in reality the pedestrian ways that acts as a link to the door to door service is not well connected so it is less secure and comfortable and unable to accommodate the needs of the urban community. The method of analysis in this study used descriptive qualitative and buffer analysis in GIS applications to identify access pedestrian connectivity to BRT shelter in Banyumanik and Pedurungan, Semarang. The results of the study are the connectivity between pedestrian ways and BRT shelter in Banyumanik is better than the connectivity in Pedurungan.
\end{abstract}

Keywords: connectivity, pedestrian ways, BRT shelter

\section{INTRODUCTION}

The high use of motorized vehicles provides a great opportunity for road construction aimed at motorized vehicle lanes without regard to other human circulation paths that are more environmentally friendly such as pedestrian networks and public transport routes. The pedestrian network is one of the public facilities that has become a necessity to accommodate the movement of people in urban areas. In principle, the development of pedestrian facilities aims to create a human area by prioritizing pedestrian comfort and safety against motorized vehicle conflict [1]. Creation of pedestrian ways brought improvements to aspects of traffic regulation, economic, environmental and social in urban areas. Therefore, the spatial aspect is often associated with travel behavior [2] [3] [4] [5]. On the other hand, the development of pedestrian ways in urban areas has many challenges because the decision to build highways for motorized vehicles takes precedence over building an integrated transportation network system. Pedestrian networks receive less attention in planning transportation systems in Indonesia. Urban roads and public facilities that are passed by public transportation are not connected to a safe and comfortable pedestrian [4]. As a result, the area becomes less accessible and less environmentally friendly because public access to BRT (Bus Rapid Transit) cannot go on foot and must use other vehicles so the cost of travel would be expensive and their travel would be inefficient. Therefore, it is important to establish a connection between the pedestrian route and the BRT (Bus Rapid Transit) route.

The city of Semarang is the capital of Central Java Province which seems to have experienced quite rapid development in terms of city development and infrastructure. City development began to develop from the center to the suburbs which were dominated by many high-rise buildings. As a result, there are small urban centers that 
encourage high intensity human activities or activities, resulting in high movement of people, goods and heavy traffic. To solve this problem, the Semarang City government has actually built transportation facilities in the form of BRT (Bus Rapid Transit) along with pedestrian paths with adequate street furniture. However, in reality the pedestrian pathway that acts as a link to the door to door service is not well connected so that it cannot accommodate the needs of the community. Based on the above problems, the research question can be formulated with "Is there any connectivity between pedestrian ways and BRT shelter in Banyumanik and Pedurungan?".

\section{Pedestrian Ways}

A pedestrian is someone that walking in the specific distance [6] [7] [8]. Whereas, pedestrian way is a safe and comfort path for pedestrians. Walking activity is the way to connect one area to another (the tool of city movement) and to fulfill the needs of interaction in commercial and culture urban [7]. The Government Regulation No. 43 Year 1993 about Utilities and Traffic Road [12], mentions about pedestrian facility as follow; a walking path facility (not include pedestrian way); crossing facilities are needed to overcome the problems with another facilities; the terminal for pedestrians (benches, bus stop, etc). Pedestrian in the city center or mixed use has good quality because it is able to provide comfort for pedestrians on Atlantic Station. Pedestrian at Atlantic Station with lighting, trees, street furniture, and parked cars buffering pedestrians from traffic, and curb cuts, signage, and crosswalk markings at every intersection. Atlantic Station has two concepts for pedestrians, namely in the city center or mixed use area, the community is directed to walk and in the suburbs the presence of small pedestrians [9]. Based on [10], features in pedestrian networks is walking area; pedestrian road link; pedestrian road link point; pedestrian road; symbol point. Walking is a part of city activities with its various purposes. Walking is one of the solution for the problems of big cities nowadays in transportation. Walking activity is the way to connect one area to another (the tool of city movement) and to fulfill the needs of interaction in commercial and culture urban. Walking is transportation mode that has unique characteristics [6] [7] [8].

\section{METHODOLOGY}

This study was conducted on Pedurungan and Banyumanik, as suburban of Semarang city area. Pedurungan located in East area of Semarang city and Banyumanik located in South area of Semarang city. The two neighborhoods areas were selected for their proximity to BRT shelter along the main street, vary in street patterns and land use. (The two maps in Fig.1.).

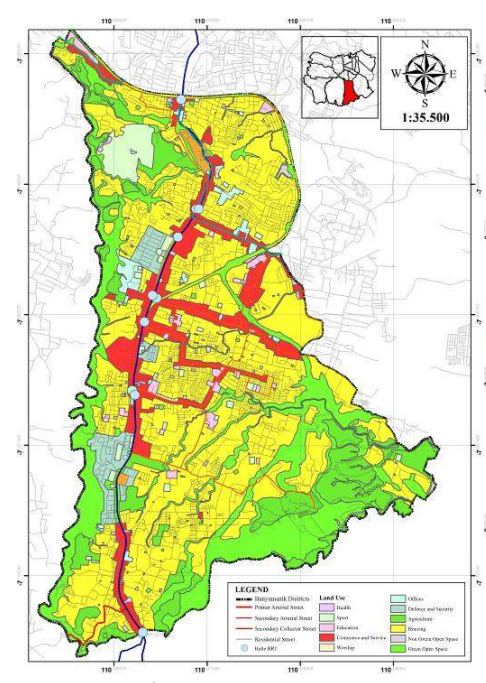

a. Banyumanik

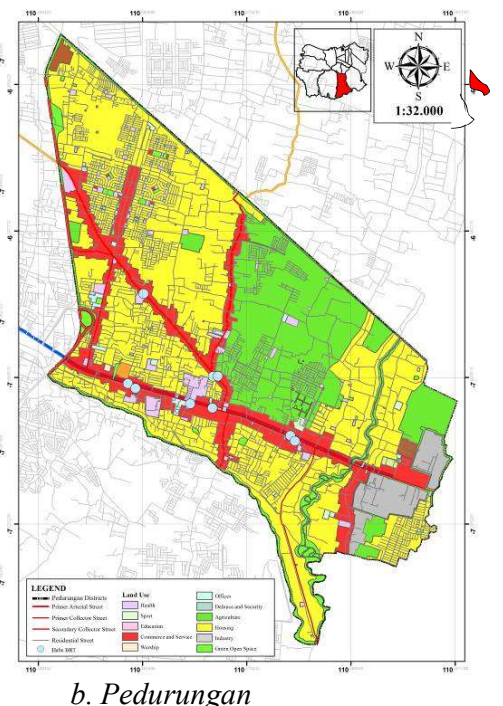

b. Pedurungan

FIGURE 1. The Study Site 
Banyumanik area is one of the oldest area in Semarang city. Banyumanik was redeveloped in the 1980s by PERUMNAS (public developer), and most buildings here are small house with wide $21 \mathrm{~m}^{2}$ and $36 \mathrm{~m}^{2}$. Differently with Banyumanik area, Pedurungan was unplanned area. Pedurungan is mixed use area with a high population density, featuring a concentration of commercial usage along the main corridor. Based on [11] in 2015, (see Fig.2) the dominant land use in this study site is office land use, trade and services, and settlements. Trade and service land use are concentrated along the main arterial roads and collector roads throughout the study site. Settlements land use tends to spread behind commercial areas which generally spread along the main road.

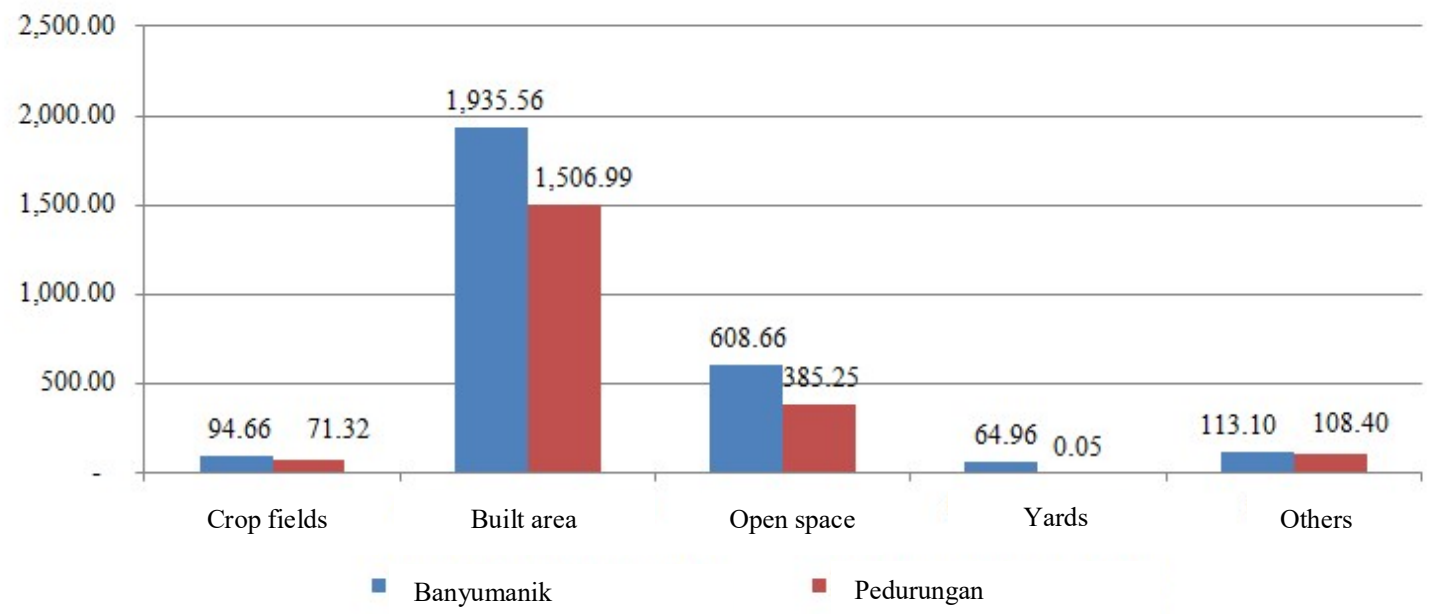

FIGURE 2. Composition of Land Use Area

Based on the graph above, the largest land use in both sub-districts is for non-agricultural functions. In Banyumanik there are various land uses such as health, sports, education, trade and services, worship, offices, defense and security, agriculture, housing, open space, green open space and socio-cultural land use. In Pedurungan there are commercial and commercial land uses along the corridor. Tertiary function is the manufacturing industry with a total industrial area of $133.37 \mathrm{Ha}$. Based on BPS data in 2015, the population of Pedurungan reached 180,282 people. The majority of the population in Pedurungan was living as industrial workers of 31,094 people or has a percentage of around $28 \%$. While the population in Banyumanik is lower than the population in Pedurungan, or about 132,508 people. The majority of the population in Banyumanik was living as civil servants/military personnel of 12,622 people or has a percentage of around $36 \%$. Regarding the number of people and land use proportion, it can be assumed that the activity of population movements on Pedurungan and Banyumanik is high every day.

This study focused on pedestrian ways and BRT shelter in Banyumanik and Pedurungan neighborhoods. This study employed a descriptive qualitative study approach to gain a holistic understanding of the connectivity of pedestrian ways and BRT shelter. Descriptive qualitative study adopts the observation method which researchers walked through around the neighborhoods area. Researchers made some observation related pedestrian ways condition access to BRT shelter. The use of GIS help to carry out coverage analysis of walking distance to access transit facilities (BRT shelter). Observation area in this study determined by analysis buffer area in GIS with coverage area 400meters from BRT shelters. The measurement of pedestrian way to access BRT shelter is 'good' when researcher found pedestrian ways and 'not-good' when researcher did not found any pedestrian ways.

\section{RESULTS AND DISCUSSION}

\section{Road Networks and BRT Shelter}

According to its function, the road in Pedurungan is divided into secondary arterial roads, primary collector roads, secondary collector roads and local roads. In Banyumanik, the roads are divided into primary arterial roads, secondary arterial roads, secondary collector roads and local roads. Location of Pedurungan is bordering Demak 
Regency and Banyumanik bordering with Ungaran Regency. The vehicle movement in these locations were quite high.

Bus Rapid Transit is a mass transit system that is designed to deliver people quickly in large quantities, affordable, safe, and comfortable. The system is designed with several supporting aspects. Administratively, BRT public passengers are given a green ticket at a rate of Rp.3500,- while for students are given a white ticket at a rate of Rp.1000,-.With the existence of BRT, it is expected to provide easy-to-reach solutions throughout the city of Semarang and its surroundings. In the study area, the BRT route is also available. Corridors that pass through Banyumanik include corridors number 2 in the Sisemut-Terboyo direction, and corridors number 6 in Sekaran Tembalang. Corridors that pass through Tembalang include corridor number 1 towards Mangkang-Penggaron, and corridor number 7 towards Terboyo-Penggaron (via Soekarno-Hatta road).

In addition to BRT, there are other public transportations that pass through the Banyumanik and Pedurungan areas. In Pedurungan, public transportation is more traversed compared to Banyumanik, this explains that the movement of activities that occur with public transportation modes is more in demand in the Pedurungan area and around eastern Semarang. With the high movement of the population in the city of Semarang, as well as the modal changes that occur, the important role of the pedestrian ways is to support the daily activities of the community. (see Fig.3)
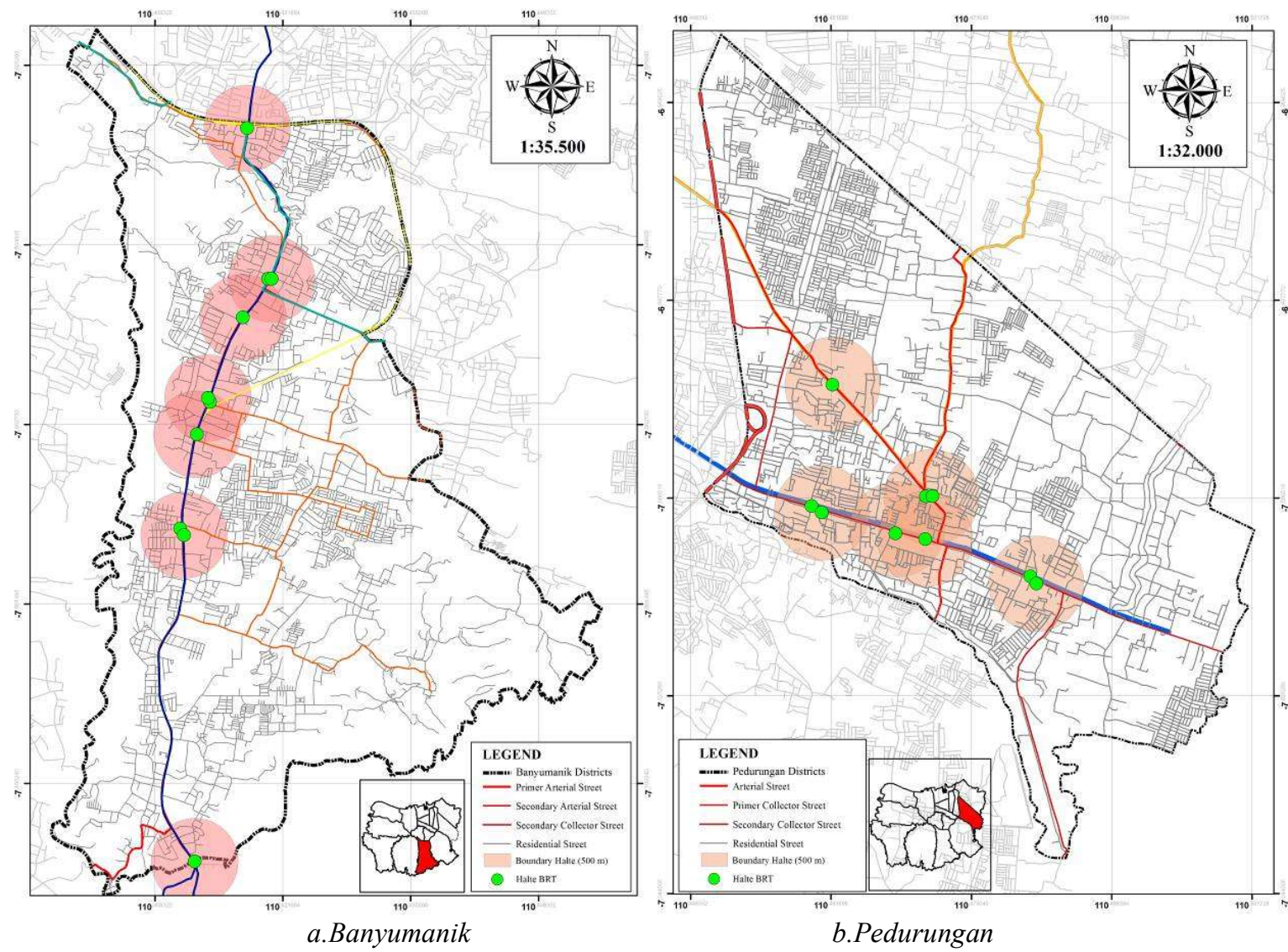

FIGURE 3. BRT Shelter Service Coverage Area in Study Site

In the observation area, there are several busway or BRT shelter as listed in the table 1. 
TABLE 1. BRT Shelter Service Coverage Area

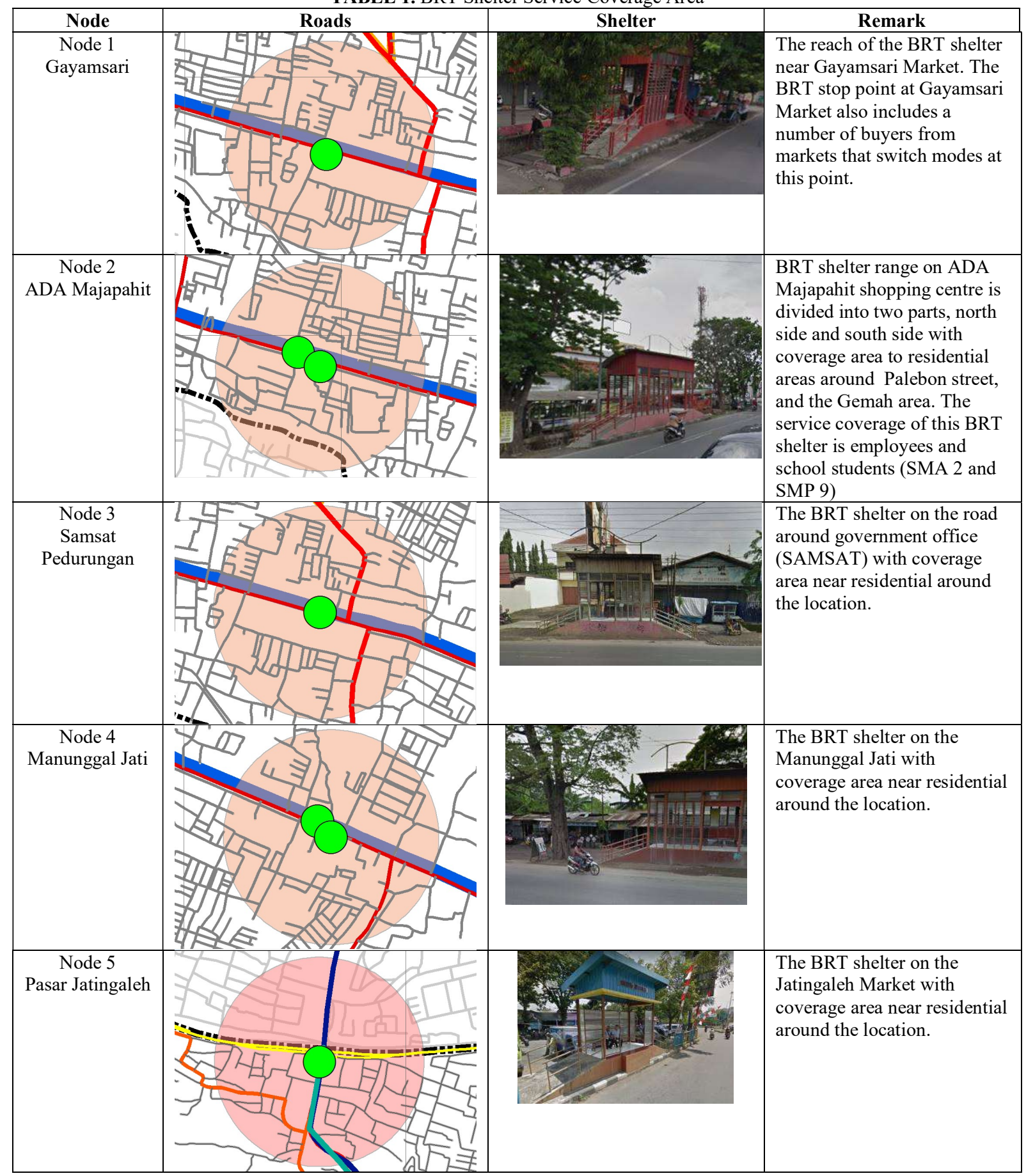




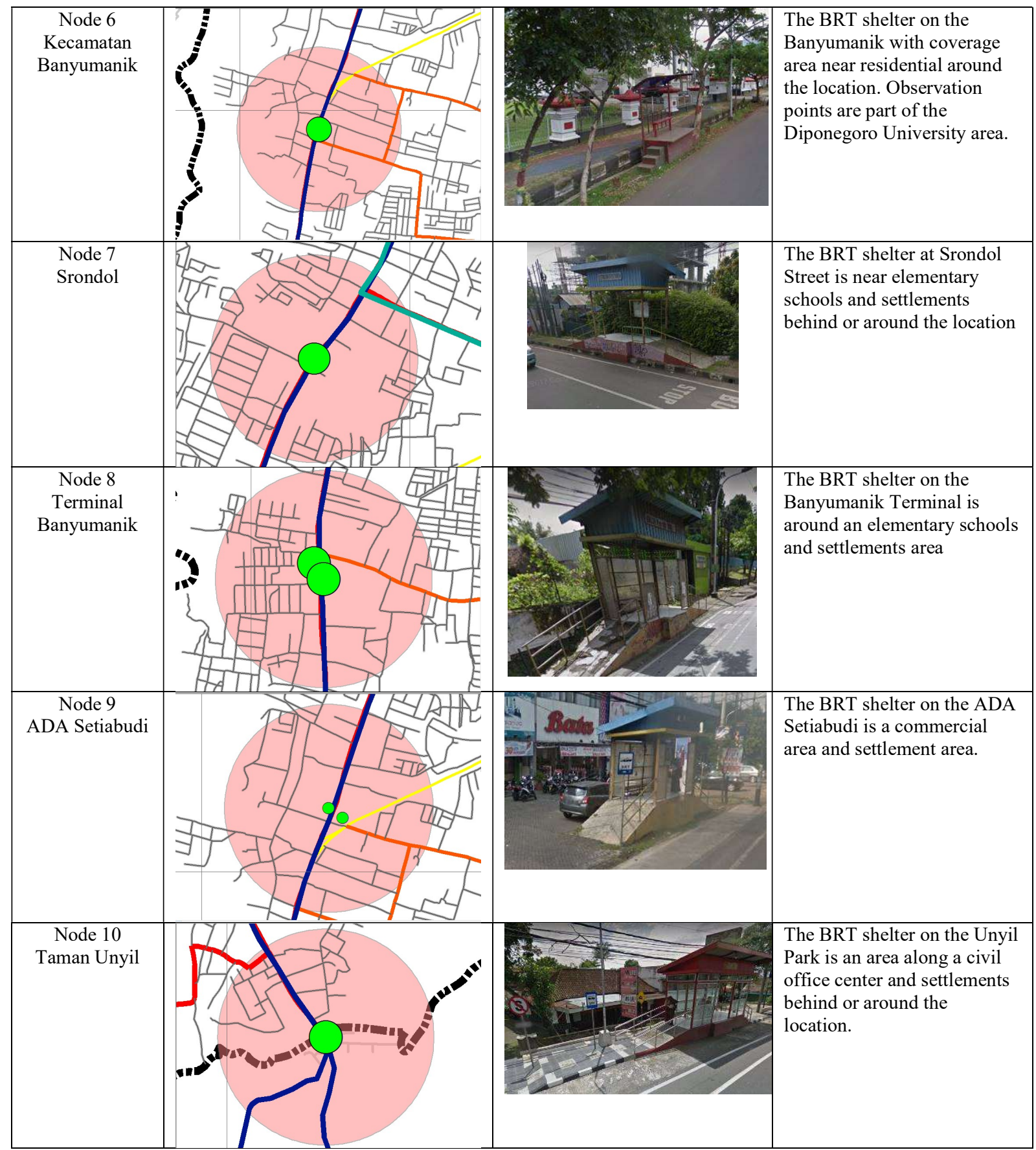

Note $:$ Node $=$ BRT shelter

Analysis buffer in GIS used coverage area 400 meters

\section{Pedestrian Ways}

Pedestrian ways do not exist in all locations in the two neighborhood areas. Several pedestrian lines are located along the arterial road, where the pedestrian route has been integrated with the Semarang BRT (Bus Rapid Transit) public transport line. The pedestrian ways conditions can be seen on table 2 . 
TABLE 2. Pedestrian Ways Condition around BRT Shelter

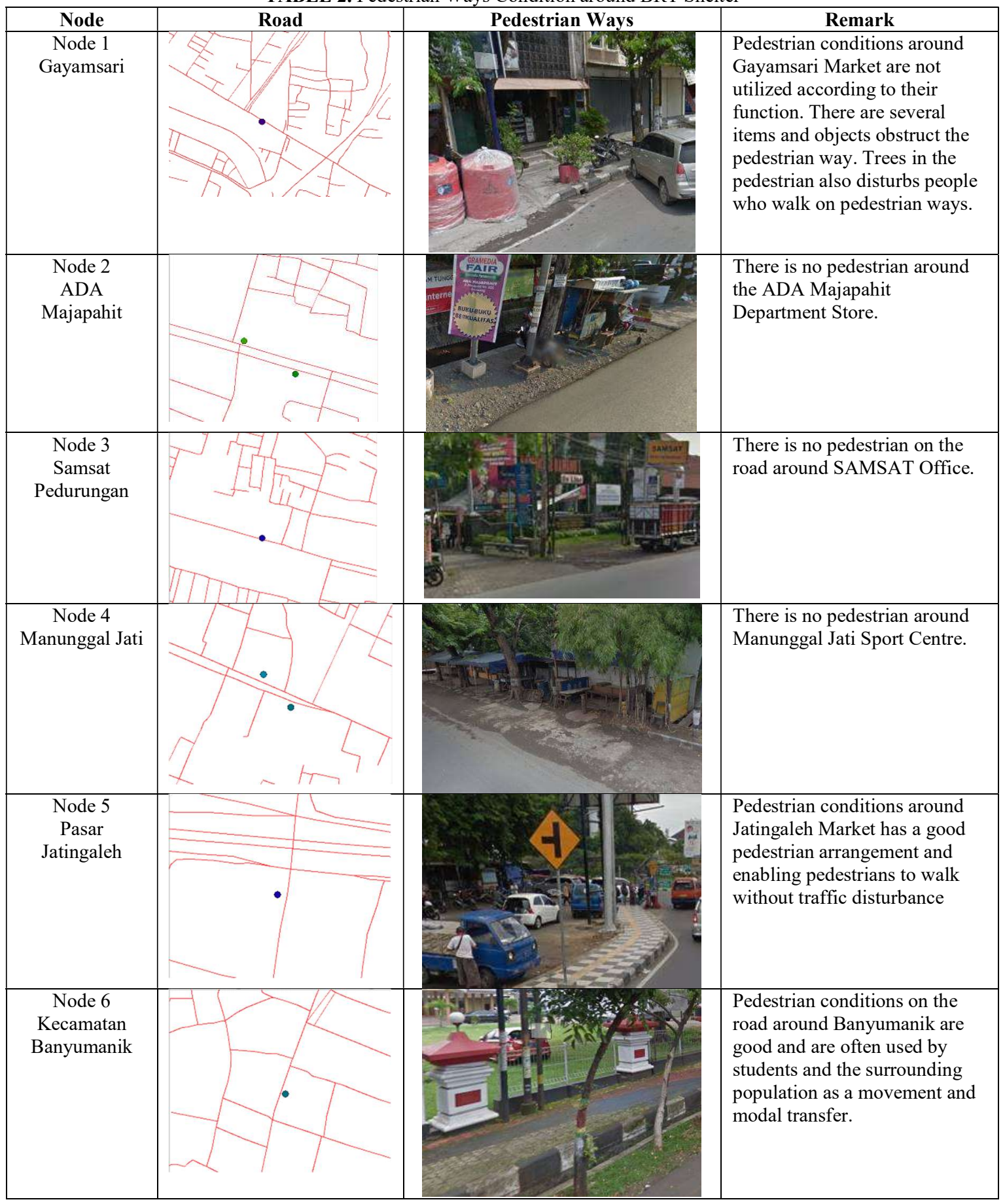




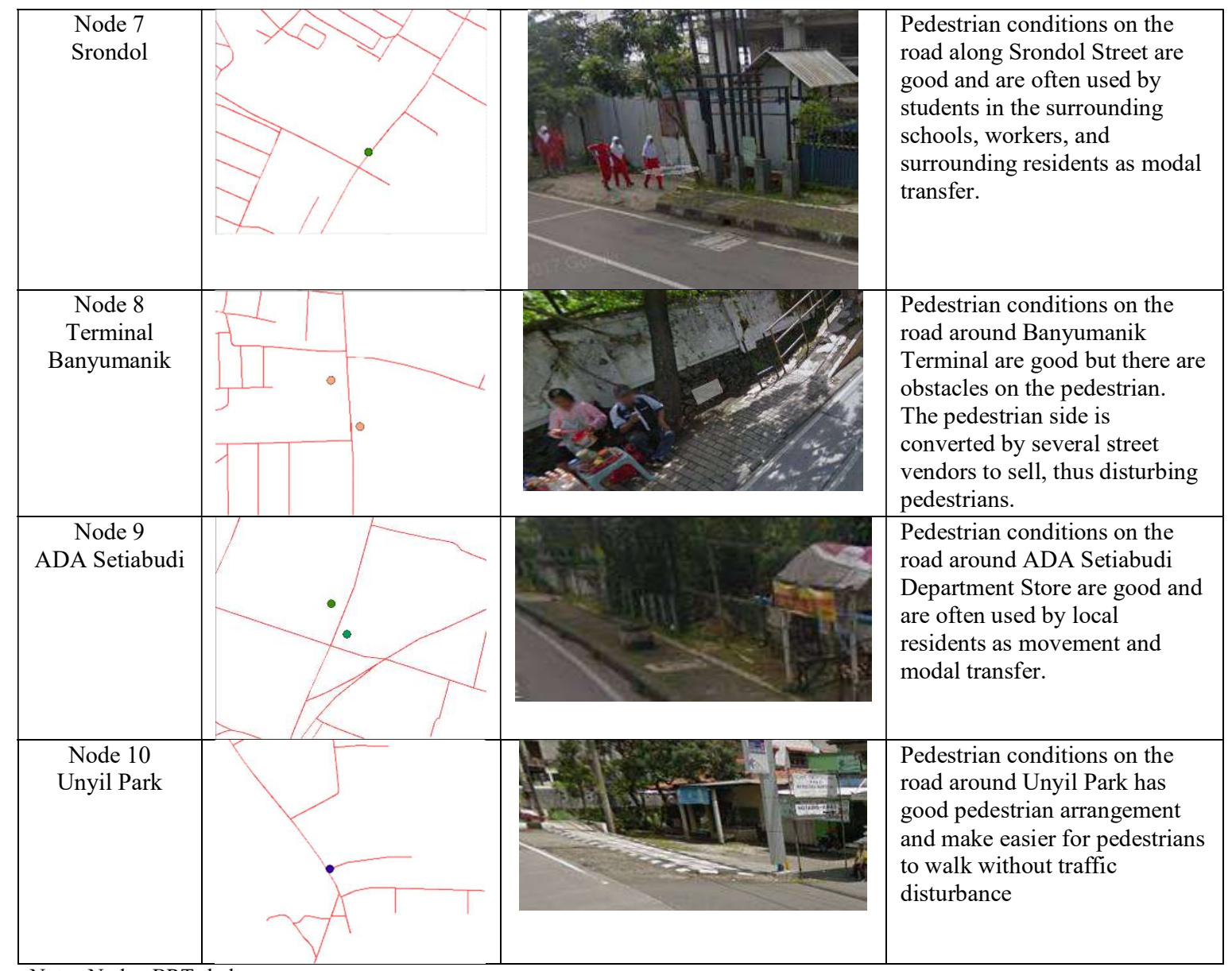

Note : Node $=$ BRT shelter

Node 1 - Node 4 = BRT Shelter in Pedurungan

Node 5 - Node $10=$ BRT Shelter in Banyumanik

The existing pedestrian ways conditions are classified as good in several locations where most of the land use is offices, commercial and educational facilities. Pedestrian ways in Banyumanik is better than Pedurungan. Pedestrian ways in Banyumanik especially around the Jatingaleh market is good because people can easily use the facility. A slightly different pedestrian ways around Banyumanik Terminal, some of pedestrian ways were used by street vendors, and difficult for pedestrians to walk. Pedestrian ways in Pedurungan from the four point samples in table 2, only one point has pedestrian route. Different things are seen in the settlement, where there is no pedestrian route. Some locations have not been connected to the pedestrian way so that local residents use the roadside to walk to public transportation.

\section{CONCLUSION}

Development of the city began to develop from the center of the outskirts of the city which was dominated by high buildings. As a result, there are small urban centers that encourage high intensity human activities or activities, resulting in high movement of people, goods and heavy traffic. To solve this problem, the Semarang City government has actually built transportation facilities like BRT (Bus Rapid Transit) shelter along with pedestrian ways with adequate street furniture. However, in reality the pedestrian ways that acts as a liaison for door to door service is not well connected so that it cannot accommodate the needs of the community.

BRT route was passed in the Banyumanik and Pedurungan whereas trade and service land use to spread along the main road and collector roads. Land use functions like settlements in the Banyumanik and Pedurungan have lower traffic densities than arterial roads. However, the pedestrian route is not found along the arterial road, 
especially in Pedurungan. The connectivity between pedestrian ways and BRT shelter in Banyumanik is good enough but still needs to be extended to settlement area to facilitate community activities. On the other side the connectivity between pedestrian ways and BRT shelter in Pedurungan is not good enough and should optimally configured.

\section{ACKNOWLEDGEMENTS}

This research was financially supported by The Faculty of Engineering, Diponegoro University, Indonesia.

\section{REFERENCES}

[1] A. Ozbila, J. Peponisb and B. Stoneb. "Understanding The Link between Street Connectivity, Land Use and Pedestrian Flows". URBAN DESIGN International, Vol. 16 (2), Macmillan Publishers Ltd. 1357-5317. 2011 pp. 125-141

[2] P. Naess, "Accessibility, Activity Participation and Location of Activities: Exploring between Residential Location and Travel Behaviour". Urban Studies, Vol. 43, No. 3, 2006.

[3] P. Næss, "Residential Self-Selection and Appropriate Control Variables in Land Use: Travel Studies", Transport Reviews, 29(3), 2009.

[4] D.I.K. Dewi, A.R. Rakhmatulloh, P. Anggraini, "Mapping Between Bus Rapid Transit Shelter and High School Location in Semarang", 2nd Geoplanning-Internasional Conference on Geomatics and Planning, IOP. Conf. Series: Earth and Environmental Science 123, 2018.

[5] A.R. Rakhmatulloh, I. Buchori, W. Pradoto, and B. Riyanto, "What is The Role of Land Value in The Urban Corridor?", 2nd Geoplanning-Internasional Conference on Geomatics and Planning, IOP. Conf. Series: Earth and Environmental Science123, 2018.

[6] A. W. Agrawal, M. Schlossberg and K. Irvin, "How Far, by Which Route and Why? A Spatial Analysis of Pedestrian Preference", Journal of Urban Design, Vol.13, No.1, 2008, pp. 81-98.

[7] R. Schneider, "Walk or Drive between Stores? Designing Neighborhood Shopping Districts for Pedestrian Activity”, Journal of Urban Design, Vol. 20, No. 2, 2015, pp. 212-229.

[8] M. Nikolopoulou, K. Martin and B. Dalton, "Shaping Pedestrian Movement through Playful Interventions in Security Planning: What do Field Surveys Suggest?", Journal of Urban Design, Vol. 21, No.1, 2016, pp. 84104.

[9] J. B. Zook, et al, "Design and pedestrianism in a smart growth development", Environment and Behavior, Vol 44, No. 2, 2012, pp. 216-234, doi: 10.1177/0013916511402060.

[10]J. Zheng, et al, "Spatial characteristics of walking areas for pedestrian navigation", 3rd International Conference on Multimedia and Ubiquitous Engineering, MUE, 2009, pp. 452-458. doi: 10.1109/MUE.2009.80.

[11]BPS, Kota Semarang dalam Angka Tahun 2015, Kantor Statistik Jawa Tengah, 2015

[12] The Government Regulation No. 43 Year 1993 about 'Utilities and Traffic Road' 